\title{
The effect of quality culture on university performance
}

\author{
Haim Hilman \\ School of Business Management \\ College of Business, Universiti Utara Malaysia \\ Ahmed Abubakar \\ Department of Business Administration \\ Federal University Kashere, Nigeria \\ Narentheren Kaliappen \\ School of Business Management \\ College of Business, Universiti Utara Malaysia
}

\section{Keywords}

Quality culture, university ranking, performance

\begin{abstract}
Higher Education sector of any country plays a pivotal role in national development. If such a key sector is weak, there is every likelihood that research, development and innovation will be week. The purpose of this study was to examine the effects of quality culture on university performance. The hypothesis was developed based on the extant literature. Data were collected from Nigerian universities via a structured questionnaire survey using the entire census. Partial Least Squares (PLS) algorithm and bootstrap techniques were used to test the study's hypothesis. The result revealed that quality culture had a significant positive effect on university performance. Based on the empirical evidence, quality culture is paramount to the success of university; therefore, universities should develop a good practice of quality culture for better performance. Improved university performance can address the problem of low-quality universities. The outcome of this study provides significant contributions to the literature.
\end{abstract}

Corresponding author: Ahmed Abubakar

Email address for corresponding author: ahmedaphd@gmail.com

First submission received: 26th January 2017

Revised submission received: 11th March 2017

Accepted: 10th April 2017

\section{Introduction}

Education, in general, contributes to economic growth and development of many nations (Khattak, 2012; Hatakenaka, 2015) with many countries strives to form a partnership with worldleading universities (Luxbacher, 2013). However, despite this importance of higher education, university performances are below expectation (Douglass, 2016; Luan, 2011). Only a few out of numerous universities are up to the world university ranking with majority lacking the merit to feature in the league table. For decades, institutions of learning have been complacent in their outlook, do not have a driven vision of a superior future, and keep on working as they have before, winding up with a rising performance gap compared with that of their national or international counterpart (Deshpande, 2014). Notwithstanding the issues in growing great academic reputations and quality in the university confront challenges of lack of resources and good governance that may build a culture of quality in numerous nations (Marginson \& Sawir, 2006). Mpaata (2010), explain that changing university custom characteristics, increase in competition, rising costs and impending crises are forces that affect academic excellence in many universities.

Previous research has addressed several aspects of quality culture of manufacturing and other service organisations (Ali and Musah, 2012; Jinhui, Wu, Zhang, and Schroeder, 2011; Koskei, Katwalo \& Asienga, 2015; Wu, 2015). Few studies were also done in the area of higher institution 
performance especially universities, with quite a number focusing on student academic performance in universities (Arulampalam, Naylor, \& Smith, 2012; Kabakchieva, 2013; Karpinski, Kirschner, Ozer, Mellott, \& Ochwo, 2013; Kostopoulos, Kotsiantis, \& Pintelas, 2015; Richardson, Abraham, \& Bond, 2012). Other scholars, attempted to outline features of best, competitive or world class universities (Aguillo, Bar-Ilan, Levene \& Ortega, 2010; Ahmed, 2015; Altbach, 2004 \& 2009; Altbach and Balan, 2007; Breakwell \& Tytherleigh, 2010; Collins \& Ho, 2014; Mpaata, 2010; Salmi, 2009 \& 2015; Shin \& Jang, 2013; Shin \& Toutkoushian, 2011) with a very little attention to the quality culture among others. In addition, other studies that add to the literature on universities performance are with an over side on measurement issues, limited items for performance measures are utilised, like the use of only research output and cumulative patent citations to scientific publications produced by individual universities (Hung, Ding, Wang, Lee, \& Lin, 2015; McCormack, Propper \& Smith, 2013). Others make use of individual staff and/or student as a unit of analysis in assessing the performance of the entire university (Ali and Musah, 2012; Kasim \& Noh, 2012; McCormack et al., 2013).

Therefore, based on preceding discussions the main purpose of this study is to answer the core research question as to what is the effect of quality culture on university performance, using a more robust university performance measures from a strategic perspective by selecting the chief executive as respondents. Thus, to examine the effect of quality culture on university performance, will add to the existing body of literature on a quality culture and university performance. The study will also enhance any further existing strategic decision guidelines on university competitiveness by providing the need for developing quality culture in the universities and higher institutions of learning.

\section{Literature review}

\section{1 concept of quality culture}

Specialists in different fields of study from alternate point of view give diverse understandings to the concept of quality culture. Some of them include Liu (2000) who believes that quality culture is simply putting quality as the center by putting quality standard, quality improvement innovation, quality management art, quality consciousness, and other spiritual and cultural activities in an organisation. Similarly, Ning (2008) points out that quality culture is the organisation in lasting quality management process, enclose quality problems arising from the activities of all manners that will reflects the organisations' unique quality viewpoint of value, including the organisation standard, moral concepts, value orientation, innovative consciousness, competitive consciousness, way of behaviour, customs, legal concept, traditional concepts, organisation system, the goal of organisation, and enterprise image among others.

Jia (2003) believes that quality culture form in an organisation by establishing and developing the process that will be rooted in the minds of all the organisational staff, deciding all the production activities of a series of quality-related values and norms. Also, Gao and Huang (2012) sees quality culture as the core part of corporate culture, which influenced by the social culture of environment and morality. The study further list uniqueness; mutability; objectivity; sociality; inheritance; and epochal character as characteristics of quality culture. Quality culture can also represent a system of values, customs, procedures and expectations which promote quality, in an environment oriented towards continually keeping and improving quality (Popa, 2005).

More comprehensively, Al-Otaibi (2015) defines quality culture as a positive reflection of the environment with commitment to quality result, process, systems, and product; it stresses upon a persistent positive change in an organisation to interwoven with the organisation's strategy, policy or mission statement and is described as a way of decisions making. It is by and large referred to as attitude and values about improving the quality level of service of an organisation (Al-Otaibi, 2015). It is used to improve employee attitude, employee communication, and customer relationship. The perfect approach to building up a practical and sustainable quality culture is by offering training on regular basis and different educational sessions Al-Otaibi added. 
Based on the above literature, the quality culture will be conceptualised in this study as the system of attitude, values, customs, procedures and expectations which promote quality, in an environment oriented organisation towards continually keeping and improving the quality level of services of an organisation.

\subsection{Quality culture and performance}

Studies exist on the variable quality culture. Jinhui et al. (2011) establish a relationship between quality exploration practices and operations performance with quality culture playing a critical role in organisational culture. Also, Gillies (2015) show how a systematic approach and supporting tools can support the development of a quality culture, and align cultural change with process improvement goals. The finding revealed that a structured approach to mentoring can deliver significant enhancements to a quality culture, complementing structured approaches to process improvement allowing alignment of cultural and process goals.

Also, $\mathrm{Wu}$ (2015) considered the impact of quality culture on quality management practices and performance. Utilising information gathered from 397 Chinese manufacturing firms in a structural equitation model. The outcomes demonstrate a chain impact that quality culture serves as a precursor for infrastructure practices to produce results and base practices give a supporting base to core practices to create positive effect on quality performance. Similarly, Ali and Musah (2012) examine quality culture and workforce performance in the Malaysian higher education sector. With a total of 267 academic staff from the International Islamic University, Malaysia completed the survey questionnaires. The findings postulate statistically significant correlation between quality culture and workforce performance. The study further suggests a replication of the study with a more systematic, probability-based sample and larger samples and more institutions of higher learning.

In addition, Koskei et al., (2015) examine the influence of quality culture on the performance of research institutions in Kenya. In analysing the data, quantitative research design utilising Analysis of Variance (ANOVA) for the analyses. The findings of the research study indicated that there was a strong relationship between quality culture and performance of research institutions in Kenya.

Furthermore, Irani, Beskese and Love (2004) found that quality culture is a continuous improvement of products and service to enhance competitiveness in the business dynamic environment. This is relevant to university performance where they are required to maintain quality standards for entire stakeholders. Again, Yusof and Ali (2000) found a significant contribution of quality culture in improving the performance of an organization as well as influencing the thought, feelings, and interaction among members of the organization. Thus, quality culture is linked to the performance of the organization.

On the basis of the above discussion and a suggestion from the work of Ali and Musah (2012) and Yorke (2000) this study is set to examine the effect of quality culture and university performance. Therefore, this study formulates the following hypothesis:

There is a positive effect of Quality Culture on University Performance

\section{Methodology}

PLS path modelling was used in assessing the effect of quality culture on university performance. The chief executive (vice chancellors) forms the respondents to this study with the institutions as unit of analysis. The choice of the management/chief executives as the respondents is due to their knowledge and experience about university performance. Hence, their views on the variables of study will help in the realisation of the set objective of this paper. The study gets a total of Ninety-nine (99) accredited universities in Nigerian as population through Nigerian Universities Commission (NUC) as at 2015 that is the body in charge of regulating Nigerian universities. The entire census was taken for data collection. A design structured questionnaire was sent to the management of each university. 
A total of 53 universities responded to the survey, constituting $53.5 \%$ response rate after a double follow-up. 44 responses was utilised for the analysis as 9 of the responses were considered problematic and excluded from the analysis, because of the issue missing data, univariate and multivariate outlier. The measurement items for the constructs of this study were adapted from previous studies. Quality culture is measured using 4 items scale adopted from the work of $\mathrm{Wu}$ (2015) with a reliability coefficient of 0.90 . While that of university performance was measured with the synthesized university performance indicators totalling 12 items adapted from Academic Ranking World University (ARWU); Quacquarelli Symonds (QS) world university rankings; Times Higher Education (THE) world university ranking; and Ranking web of universities (Webometrics) based on teaching, internationalisation, research, size, impact and prestige, which were subjected to face validity and reliability test. The study found the items reliable with an alpha coefficient of 0.98 . In line with previous studies, we used a five-point Likert-type scale to measure the items. The scales for both the quality culture and university performance range from "strongly disagree" to "strongly agree."

\section{Results and discussion}

To analyze the research model, we employed the Partial Least Squares (PLS) analysis technique using the Smart PLS 3.0 software (Ringle, Wende \& Becker, 2015). Following the recommended two-stage analytical procedures by Anderson and Gerbing (1988), we tested the measurement model (validity and reliability of the measures) followed by an examination of the structural model (testing the hypothesized relationships) (see Hair, Hult, Ringle, \& Sarstedt, 2016; Ramayah, Lee, \& Boey, 2011). To test the significance of the path coefficients and the loadings, a bootstrapping method was used (Hair et al. 2016)

Measurement model evaluation

To assess the measurement model reliability and validity were examined through the Cronbach's alpha coefficient, factor loadings, the index of composite reliability and average variance extracted (AVE) (Gholami, Sulaiman, Ramayah, \& Molla, 2013). The factor loadings of all items but one has achieved a level of significance, Item coded UP3 was deleted due to low loading. Alpha coefficients were all higher than 0.7, the composite reliabilities were all above 0.7 and the AVE values were also higher than 0.5 as suggested by Hair et al. (2016) (see Table 1)

Table 1: measurement model

\begin{tabular}{llllll}
\hline Construct & Items & Loadings & Cronbach's Alpha & CR & AVE \\
\hline Quality Culture & QC1 & 0.946 & 0.910 & 0.938 & 0.790 \\
& QC2 & 0.829 & & & \\
QC3 & 0.939 & & & \\
University Performance & QC4 & 0.835 & & & \\
& UP1 & 0.968 & 0.978 & & 0.831 \\
& UP2 & 0.966 & & & \\
& UP4 & 0.736 & & & \\
& UP5 & 0.969 & & & \\
& UP6 & 0.969 & & & \\
& UP7 & 0.975 & & & \\
& UP8 & 0.739 & & & \\
& UP9 & 0.752 & & & \\
& UP10 & 0.963 & & & \\
& UP11 & 0.957 & & & \\
& UP12 & 0.971 & & & \\
\end{tabular}




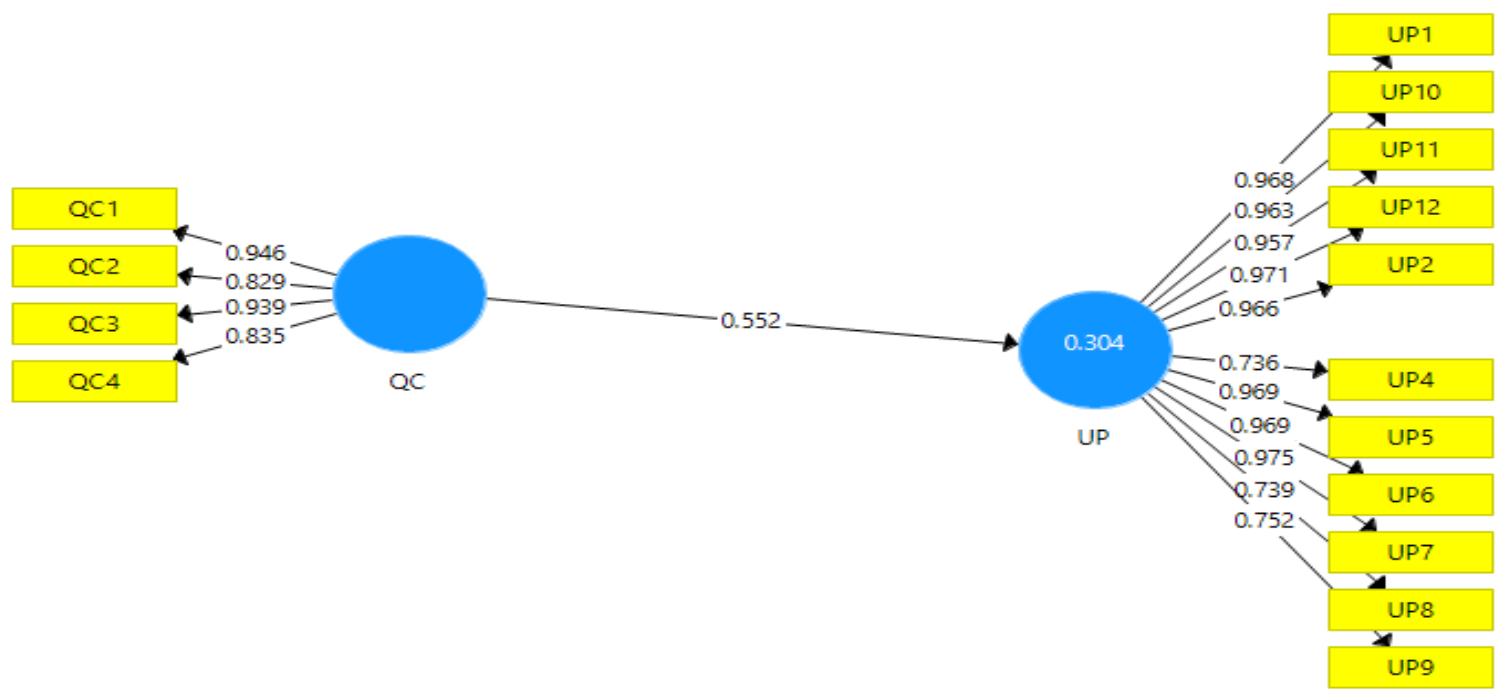

Figure 1

SmartPLS Algorithm Graph for the study

Structural model evaluation

Assessing the structural model involves evaluating $\mathrm{R}^{2}$, beta and the corresponding $\mathrm{t}$-values (Hair et al. 2016). To obtain the t-values, a bootstrapping procedure with 5000 resample was applied. Therefore, the bootstrapping result from the Smart PLS on the effect of quality culture on university performance shows acceptance for the hypothesis. The result reveals that path coefficient from quality culture to university performance (QC -> UP) is statistically significant with a beta $(\beta)$ value of 0.552 , $t$-value of 8.310 and a $p$-value of 0.000 significant at the $p<0.01$ (see Table 2).

Table 2

Path Coefficients

\begin{tabular}{llcccccc}
\hline Hypotheses & $\begin{array}{l}\text { Indirect } \\
\text { Relationship }\end{array}$ & Beta $(\boldsymbol{\beta})$ & $\begin{array}{c}\text { Standard } \\
\text { Erro }\end{array}$ & $\begin{array}{c}\text { T } \\
\text { Statistics }\end{array}$ & P value & Decision & $\mathbf{R}^{2}$ \\
\hline & & & & & & & \\
H1 & QC $->$ UP & 0.552 & 0.066 & 8.310 & 0.000 & Supported & 0.304 \\
\hline
\end{tabular}

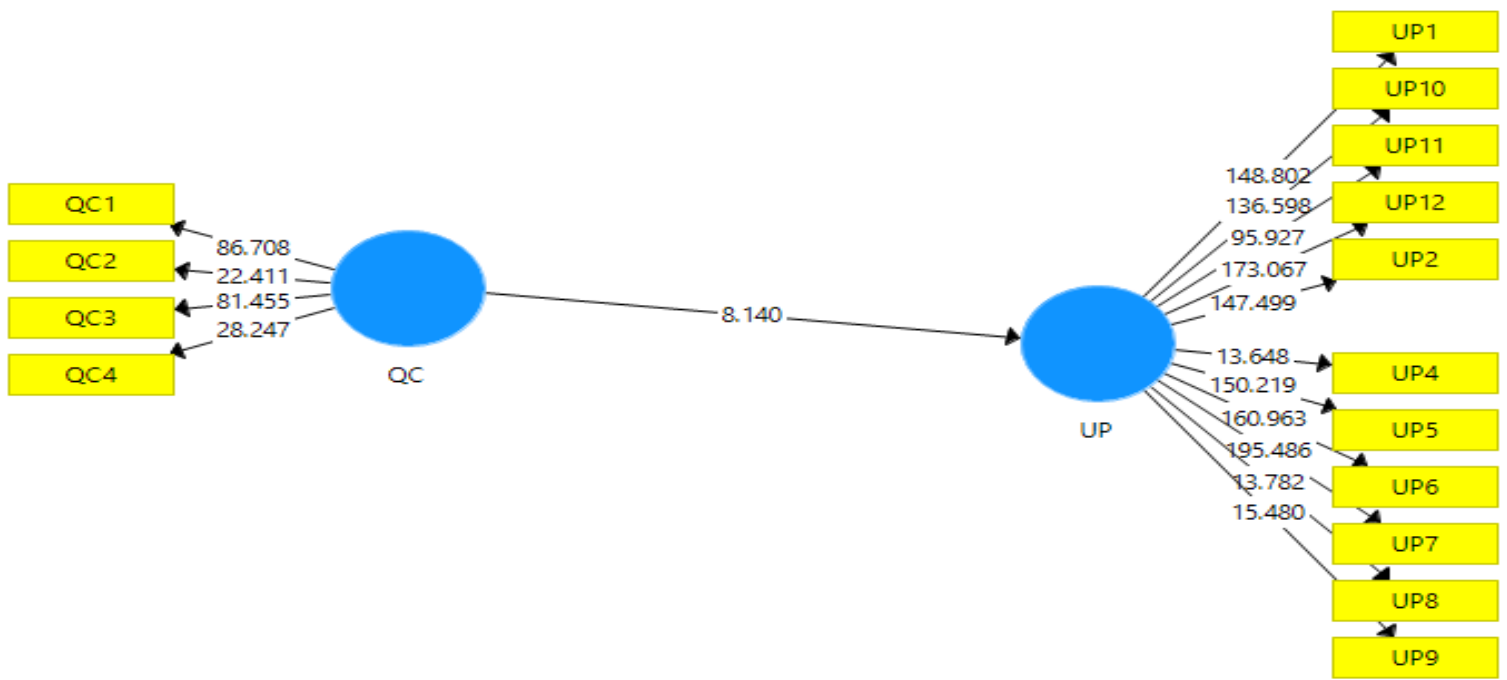

Figure 2

SmartPLS Bootstrap Graph for the study 
Though, it was suggested that a good parsimonious model is the one with high $\mathrm{R}^{2}$ value explained by relatively fewer independent latent variables. As in this case the $\mathrm{R}^{2}$ value is 0.304 and it deemed satisfactorily since it has exceeded 1.5 percent as argued by Falk and Miller (1992). The low $\mathrm{R}^{2}$ value is not surprise due to the nature of the model with only one independent variable to the dependent.

On the general note, the finding has empirically reveals that quality culture has significant positive effect on university performance. The implication of this finding is that the higher the level of quality culture the more a university will perform. Quality culture is the system of attitude, values, customs, procedures and expectations which promote quality, in an environment oriented organisation towards continually keeping and improving the quality level of services of an organisation.

The implication of this finding is that the vice chancellors of the Nigerian universities supported the contribution of quality culture to the performance of universities. Therefore, the finding of this study implies that for varsities to compete favourable in the ranking table it need to develop a quality culture practices where the behaviour, attitude, and expectations of all the stakeholders is guided towards continually keeping and improving the quality level of services of the universities. In other words, university management should have a continuous improvement plan that is supported by innovation that can build a strong culture, which can positively improve the universities' competitiveness. This will go a long way in improving the performance of the universities.

In addition, this result is consistent with Ali and Musah (2012); Koskei et al., (2015); Wu (2015) who reveal a positive association between quality culture and performance. For example, Irani et al. (2004) found that quality culture is a continuous improvement of products and service to enhance competitiveness in the business dynamic environment. This is relevant to university performance where they are required to maintain quality standards for entire stakeholders. Again, Yusof and Ali (2000) found a significant contribution of quality culture in improving the performance of an organization as well as influencing the thought, feelings, and interaction among members of the organization. Thus, quality culture is linked to the performance of the organization.

\section{Conclusion}

In conclusion, the research objective is to examine the effect of quality culture on university performance. The finding of this relationship was supported based on the empirical validation. This indicated that quality culture is a determinate of university performance. Therefore, issues regarding quality culture should be of priority to university management.

\section{Limitations and Future Research}

Even though, the study made theoretical and practical contributions to the university performance. Some limitations exist for that need to be noted and addressed. The first limitation is that, even though there are so many variables in existence that may predict university performance, this study is limited to quality culture as guided by the existing literature. The research model could explain only $30.4 \%$ of the total variance in university performance, which means there are other latent variables that could significantly explain the variance. Again, the scope of the research was limited to the Nigerian universities alone.

To conquer the above limitations, this study recommends that future studies be conducted using other variables that can make significant predictions of university performance. The direct relationship suggested that construct amounting $69.6 \%$ may have a strong positive relationship with the criterion variable. A future research should consider a wider scope with university across west Africa and beyond. 


\section{References}

Aguillo, I. F., Bar-Ilan, J., Levene, M., \& Ortega, J. L. (2010). Comparing university rankings. Scientometrics, 85(1), 243-256.

Ahmed, H. O. K. (2015). Strategic approach for developing world-class Universities in Egypt. Journal of Education and Practice, 6(5), 125-145.

Ali, M. H., \& Musah, B. M. (2012). Investigation of Malaysian higher education quality culture and workforce performance. Quality Assurance in Education, 20(3), 289-309.

Al-Otaibi, F. M. S. (2015). Role of exploratory factor analysis applicability of TQM practices on the items of quality culture in the kingdom of Saudi Arabia. International Journal of Business and Management, 10(1), 136-143.

Altbach, P. G. (2004). Globalisation and the university: Myths and realities in an unequal world. Tertiary Education \& Management, 10(1), 3-25.

Altbach, P. G. (2009). Peripheries and centers: Research universities in developing countries. Asia Pacific Education Review, 10(1), 15-27.

Altbach, P. G., \& Balan, J. (2007). World class worldwide: Transforming research universities in Asia and Latin America. JHU Press

Anderson, J. C., \& Gerbing, D. W. (1988). Structural equation modeling in practice: A review and recommended two-step approach. Psychological bulletin, 103(3), 411.

Arulampalam, W., Naylor, R. A., \& Smith, J. (2012). Am I missing something? The effects of absence from class on student performance. Economics of Education Review, 31(4), 363-375.

Breakwell, G. M., \& Tytherleigh, M. Y. (2010). University leaders and university performance in the United Kingdom: is it 'who 'leads, or 'where 'they lead that matters most?. Higher

Education, 60(5), 491-506.

Collins, F. L., \& Ho, K. C. (2014). Globalising higher education and cities in Asia and the Pacific. Asia Pacific Viewpoint, 55(2), 127-131.

Deshpande, M. (2014). Entrepreneurship Approach to Higher Education Policy Aspects. Handbook of Research on Higher Education in the MENA Region: Policy and Practice: Policy and Practice, 148.

Douglass, J. A. (2016, December 2). University leadership 'poor' quality, says higher education scholar. Times Higher Education. Retrieved from

https://www.timeshighereducation.com/news/university-leadership-poor-quality-says-highereducation-scholar.

Falk, R. F., \& Miller, N. B. (1992). A primer for soft modeling. University of Akron Press.

Gao, Z., Ye, J., \& Huang, Y. (2012). Study on the Construction of Enterprise Quality Culture for Brand Strategy. iBusiness, 4(3), 260-264.

Gholami, R., Sulaiman, A. B., Ramayah, T., \& Molla, A. (2013). Senior managers' perception on green information systems (IS) adoption and environmental performance: Results from a field survey. Information $\mathcal{E}$ Management, 50(7), 431-438.

Gillies, A. C. (2015). Tools to support the development of a quality culture in a learning organisation. The TQM Journal, 27(4), 471-482.

Hatakenaka, S. (2015). The role of higher education institutions in innovation and economic development. International Higher Education, (47).

Hung, W. C., Ding, C. G., Wang, H. J., Lee, M. C., \& Lin, C. P. (2015). Evaluating and comparing the university performance in knowledge utilization for patented inventions. Scientometrics, 102(2), 1269-1286.

Irani, Z., Beskese, A., \& Love, P. E. D. (2004). Total quality management and corporate culture: constructs of organisational excellence. Technovation, 24(8), 643-650.

Jia, H., (2003). Enterprise quality culture construction and enterprise quality management, Journal of Engineering Quality, 46(10), 175-180.

Jinhui Wu, S., Zhang, D., \& Schroeder, R. G. (2011). Customization of quality practices: the impact of quality culture. International Journal of Quality and Reliability Management, 28(3), 263-279. 
Kabakchieva, D. (2013). Predicting student performance by using data mining methods for classification. Cybernetics and information technologies,13(1), 61-72.

Karpinski, A. C., Kirschner, P. A., Ozer, I., Mellott, J. A., \& Ochwo, P. (2013). An exploration of social networking site use, multitasking, and academic performance among United States and European university students. Computers in Human Behavior, 29(3), 1182-1192.

Kasim, R. S. R., \& Noh, I. (2012). The impact of organisational innovativeness on the performance of the university: An analysis among selected Malaysian private universities. in Innovation Management and Technology Research (ICIMTR), 2012 International Conference on (pp. 1-5). IEEE.

Khattak, N. U. R. (2012). The contribution of education to economic growth: evidence from Pakistan. International Journal of Business and Social Science, 3(4), 145-151.

Koskei, R., Katwalo, A. M., \& Asienga, I. (2015). Influence of Quality Culture on Performance of Research Institutions in Kenya. African Journal of Business $\mathcal{E}$ Economic Research, 10(1), 25-54.

Kostopoulos, G., Kotsiantis, S., \& Pintelas, P. (2015). Predicting Student Performance in Distance Higher Education Using Semi-supervised Techniques. In Model and Data Engineering (pp. 259-270). Springer International Publishing.

Liu, L. M. (2000). On enterprise quality culture aesthetic evaluation, Journal of Metallurgical Standardization and Quality, 18 (1), 69-72

Luan, P. V. (2011, December 4). VIETNAM: Higher education quality poor, says minister. University World News. Retrieved from

http://www.universityworldnews.com/article.php?story=2011120222340 338

Luxbacher, G. (2013). World University Rankings: How much influence do they really have? The Guardian. Retrieved from http:/ / www.theguardian.com

Marginson, S., \& Sawir, E. (2006). University leaders' strategies in the global environment: A comparative study of Universitas Indonesia and the Australian National University. Higher Education, 52(2), 343-373.

McCormack, J., Propper, C., \& Smith, S. L. (2013). Herding cats? Management and university performance. The Economic Journal, 124 (August), F534- F564.

Mpaata, A. K. (2010). University Competiveness through Quality assurance; The Challenging Battle for Intellectuals.

Ning, H., (2008) Discussion on enterprise quality culture significance, Journal of Science and Technology Information, 5(18), 71-76.

Popa, F. (2005). The culture of quality-the essential condition for the institutions involved in changing management. in International Conference on Management and Industrial Engineering (p. 306). Niculescu Publishing House.

Ramayah, T., Lee, J. W. C., \& In, J. B. C. (2011). Network collaboration and performance in the tourism sector. Service Business, 5(4), 411-428.

Richardson, M., Abraham, C., \& Bond, R. (2012). Psychological correlates of university students' academic performance: a systematic review and meta-analysis. Psychological bulletin, 138(2), 353.

Ringle, C. M., Wende, S., \& Becker, J. M. (2015). SmartPLS 3. Boenningstedt: SmartPLS GmbH, http://www. smartpls. com.

Salmi, J. (2009). The challenge of establishing world-class universities. World Bank.

Salmi, J. (2015). To Be or Not to Be-A World-Class University?. International Higher Education, (80), 17-18.

Shin, J. C., \& Jang, Y. S. (2013). World-class university in Korea: Proactive government, responsive university, and procrastinating academics. In institutionalization of world-class university in global competition (pp. 147-163). Springer Netherlands

Shin, J. C., \& Toutkoushian, R. K. (2011). The past, present, and future of university rankings, in University Rankings (pp. 1-16). Springer Netherlands. 
$\mathrm{Wu}, \mathrm{S}$. J. (2015). The impact of quality culture on quality management practices and performance in Chinese manufacturing firms. International Journal of Quality $\mathcal{E}$ Reliability Management, 32(8), 799-814.

Yorke, M. (2000). Developing a quality culture in higher education. Tertiary Education and Management, 6(1), 19-36.

Yusof, A., \& Ali, J. (2000). Managing culture in organization. Malaysian Management Journal, 35(2), 6065 